\title{
OBITUARIES
}

\section{Dr. J. L. Pawsey, F.R.S.}

Dr. Joseph Lade Pawsey, Australia's pioneer in radio astronomy, died in Sydney on November 30, aged fiftyfour. Dr. Pawsey was assistant chief of the Division of Radiophysics of the Commonwealth Scientific and Industrial Research Organization, which he had joined early in 1940 and where he directed the Division's radio astronomy work during the seventeen years preceding his death. During 1962 he was to have taken up a new appointment in the United States as director of the National Radio Astronomy Observatory at Green Bank, West Virginia. It was during a preliminary visit to the United States early in 1962 in preparation for this appointment that he became seriously ill, and it was only due to the medical skill and devotion given him through the efforts of his American colleagues that he lived long enough to return home to his family and indeed to accomplish a final work - the editing of a large collection of radio astronomical works shortly to be published. $\mathrm{He}$ is survived by his wife, two sons and a daughter.

Dr. Pawsey's interest in radio astronomy began while working on radar developments during the Second World War when confidential reports became available of the discovery of radio-frequency radiation from the Sun. After the War he began exploring these emissions and soon discovered that metre waves from the Sun consisted of two components - a basic thermal component from the Sun's million-degree corona, and a much more intense variable component which he accurately located in the vicinity of sunspots. From the impetus of these observations he began to form around him a group of physicists and engineers which was to play a leading part in the evolution of the new science of radio astronomy. Dr. Pawsey devoted most of his time to encouraging and stimulating this group, guiding them with inexhaustible patience and skill into a weries of crucial experiments which helped to reveal the nature of the radio universe. The first unambiguous demonstration of the existence of radio stars, their first identifications with visible objects (nebulæe and galaxies as we now know), the mapping of the sky over a great range of frequencies, including the $21-\mathrm{cm}$ emission of hydrogen, the detailed exploration of the complex emissions from the Sun, quiet and disturbed, and the interpretation of solar bursts in terms of matter expelled from solar explosions-these are a few of the contributions made by his group during his years of directorship. His interest in the astronomical results was matched by his interest in the development of the techniques required for obtaining them (he had, during the five years before the War, been intimately connected with the development of the original television system at Alexandra Palace), and again his group became known for novelty of approach to instrumental problemsvarious types of interferometers, the solar radio spectrograph, the grating aerial array, the Mills Cross and the multi-channel hydrogen spectrograph were all developed under his leadership. In the stimulus he gave his group for methods of obtaining higher and higher angular resolution, his interest lay more in the application of the principles of interferometry than in the conventional 'big-dish' approach; but when the decision was made to build a 210 -ft. radio telescope for the Laboratory, he threw his energies into organizing the preparation of first-class receiving equipment needed to ensure its success.

Dr. Pawsey will be particularly remembered by his group for his ability to simplify complex problems and situations by pointing to the heart of the matter, for his willingness to discuss any aspect of a problem at all times at any level, and for his decisive and positive criticism of any manuscript or project put boforo him. Ho will also be remembered by his many friends across the world for his absolute integrity and honesty throughout his work and personal life.

Dr. Pawsoy was made a Foundation Fellow of the Australian Academy of Science in 1954, and was elected Fellow of the Royal Society in the same year. He was awarded the Lyle Medal of the Australian Academy in 1954, and the Hughes Medal of the Royal Society in 1960. International recognition of his work was signified by his election as president of the Radio Astronomy Commission of the International Astronomical Union between 1952 and 1958 .

His publications, though extensive, give no indication of his real contributions unless one reads the acknow ledgments at the conclusion of scores of papers written by other authors. His most comprehensive work, in collaboration with Prof. R. N. Bracewell, is the elassical text-book on Radio Astronomy.

Dr. Pawsey was a graduate of the University of Melbourne, where, in 1931, he won an 1851 Exhibition Scholarship to take his Ph.D. at the Cavendish Laboratory under Lord Rutherford. One may sense something of Rutherford's influence both in his love of the simple direct exporiment and in his achievement of establishing the kind of group in which every member acquires the confidence and individuality to play his part in international research. J. P. WIILD

\section{Prof. John J. Bittner}

EXPERIMENTAL mammary tumour pathology suffered a great loss by the death in Minneapolis, on December 14, 1961, of Prof. John J. Bittner.

Born on February 25, 1904, in Meadville, Pa., he was educated at St. Stephen's College (now Bard), Annandale. on-Hudson, New York, where he earned his A.B. degree in 1925. He received his M.S. in 1929, and Ph.D. in 1930, at the University of Michigan.

Bittner was assistant in cancer research (1927-30) in the University of Michigan; research associate (1930-40) and assistant director (1940-42) at Roscoe B. Jackson Memorial Laboratory, Bar Harbor, Maine; George Chase Christian professor of cancer research and director of cancer biology (1942-61) and professor of experimental pathology (1957-61) in the Medical School of the University of Minnesota; consulting associate scientist of the Sloan-Kettering Institute (1956-61).

Until about thirty years ago, it was generally agreed that mammary cancer in mice developed as the result of hormonal stimulation acting on susceptible tissues having the hereditary factor. In 1933 the situation of the causative factors of mammary tumours in mice began to change because the staff of Roscoe B. Jackson Memorial Laboratory announced the discovery of a non-chromosomal influence of maternal origin, which played a decisive part in the development of spontaneous mammary tumours in mice.

In 1936 , Bittner wrote in a famous preliminary report: "Should further study demonstrate that the incidence of mammary gland tumours in mice may be affected by nursing, an explanation may be offered for the so-called extrachromosomal influence as a cause in the development of this type of neoplasm".

Bittner's major discovery (1939) was to identify this extrachromosomal influence with nursing, that is, with the milk factor. 